\title{
Stability and energy characteristics of extended nitrogen nanotubes: density functional theory study
}

\author{
K. S. Grishakov ${ }^{\dagger, 1}$, K. P. Katin ${ }^{1,2}$, M. A. Gimaldinova ${ }^{1}$, M. M. Maslov ${ }^{1,2}$ \\ †ksgrishakov@yahoo.com \\ ${ }^{1}$ National Research Nuclear University “MEPhI”, 31 Kashirskoe shosse, Moscow, 115409, Russia \\ ${ }^{2}$ Research Institute for the Development of Scientific and Educational Potential of Youth, \\ 14/55 Aviatorov St., Moscow, 119620, Russia
}

\begin{abstract}
We apply the density functional theory with B3LYP exchange-correlation energy functional and the basis set 6-31G(d) to investigate structural, energetic, and electronic properties and stability of extended armchair and zigzag nitrogen nanotubes with a length of $\approx 3 \mathrm{~nm}$. The capping effect, as well as the passivation of nanotubes' ends by hydrogen atoms and hydroxyl groups on their stability, are studied. According to our calculations, pristine nitrogen nanotubes are unstable. Both capping and passivation of the nanotube ends provide thermodynamic stability only for $(3,0)$ and $(4,0)$ zigzag nitrogen nanotubes. Moreover, the calculated frequency spectra of considered systems confirm their dynamic stability. We stress the fact that some extended nitrogen nanotubes are found to be stable under ambient conditions, i. e., in the absence of external factors such as pressure, spatial confinement, etc. The calculated HOMO-LUMO gaps for these stable extended systems are of the order of $4 \mathrm{eV}$, so they can be assigned to the class of insulators. It is shown that nitrogen nanotubes are able to store a large amount of energy and can be used as a basis for new high-energy-density materials. We expect that the all-nitrogen tubes with the longer effective length of similar chiralities are also should be stable.
\end{abstract}

Keywords: nitrogen nanotubes, density functional theory, high-energy-density materials.

УДК: $538.911 ; 544.223 .221 ; 544.225$

\section{Исследование устойчивости и энергетических характеристик протяженных азотных нанотрубок в рамках теории функционала плотности}

\author{
Гришаков К.С. ${ }^{\dagger, 1}$, Катин К. П. ${ }^{1,2}$, Гимальдинова М. А. ${ }^{1}$, Маслов М. М. ${ }^{1,2}$ \\ ${ }^{1}$ Национальный исследовательский ядерный университет «МИФИ», Каширское ш., 31, Москва, 115409, Россия \\ ${ }^{2}$ Научно-исследовательский институт проблем развития научно-образовательного потенциала молодёжи, \\ ул. Авиаторов 14/55, Москва, 119620, Россия
}

B рамках теории функционала плотности с обменно-корреляционным функционалом B3LYР и электронным базисом 6-31G(d) исследованы структурные, энергетические и электронные свойства, а также устойчивость протяженных кресельных и зигзагообразных азотных нанотрубок длиной $\approx 3$ нм. Изучено влияние концов нанотрубок на их устойчивость: рассматривались как закрытые полусферическими окончаниями концы, так и открытые трубки, пассивированные атомами водорода и гидроксильными группами. Согласно проведенным расчетам, исходные азотные нанотрубки с открытыми и непассивированными концами - нестабильны. Как закрытые, так и пассивированные концы обеспечивают термодинамическую устойчивость только для $(3,0)$ и $(4,0)$ зигзагообразных азотных нанотрубок. Рассчитанные частотные спектры этих двух трубок подтверждают их динамическую устойчивость. Подчеркнем, что указанные протяженные нанотрубки устойчивы при нормальных условиях, т.е. при отсутствии внешних факторов, таких как давление, пространственное ограничение и т.д. Рассчитанные энергетические щели для стабильных протяженных систем составляют около 4 эВ, поэтому их можно отнести к классу изоляторов. Показано, что азотные нанотрубки способны накапливать большое количество энергии и могут использоваться в качестве основы для новых материалов с высокой плотностью энергии. Мы ожидаем, что азотные нанотрубки с указанными хиральностями устойчивы и при больших эффективных длинах.

Ключевые слова: азотные нанотрубки, теория функционала плотности, материалы с высокой плотностью энергии. 


\section{Introduction}

Nitrogen-rich compounds attracted considerable attention for a long time due to their great potential for creating high-energy-density materials (HEDM). Under normal conditions, nitrogen exists as diatomic $\mathrm{N}_{2}$ molecules with an extremely strong triple covalent bond, making $\mathrm{N}_{2}$ chemically inert. The energy of the triple bond $\mathrm{N} \equiv \mathrm{N}$ is $229 \mathrm{kcal} / \mathrm{mol}$, while the double bond energy $\mathrm{N}=\mathrm{N}$ is $100 \mathrm{kcal} / \mathrm{mol}$, and the single bond $\mathrm{N}-\mathrm{N}$ is even weaker, and its energy is only $38.4 \mathrm{kcal} / \mathrm{mol}$ [1]. Thus, for nitrogen, the sum of the energies of three single bonds is much less than the energy of the triple bond, which allows one to create the allotropic modifications of nitrogen, consisting of single and double bonds, to store energy that can be used as next-gen fuel elements. Moreover, their subsequent decomposition is environmentally friendly since it leads to the formation of non-toxic $\mathrm{N}_{2}$.

In 1992, it was theoretically predicted that the most likely form of the polymeric nitrogen at high pressure is the cubic gauche phase [2]. Its existence was proved in 2004 using the experiments with diamond anvil cells at the pressure of $110 \mathrm{GPa}$ and the temperature of $2000 \mathrm{~K}$ [3]. Subsequently, it was theoretically predicted a number of new stable crystalline nitrogen forms, such as the metallic phase with a chainlike structure [4], $\mathrm{Cmcm}$ chain [5], layered boat [6], poly-N [7], chaired web [8], black phosphorus [9], the layered $\mathrm{Pba} 2$ and the helical tunnel $\mathrm{P} 2{ }_{1}{ }_{1}{ }_{1}$ structures [10], $\mathrm{P} 4 / \mathrm{nbm}$ phase [11], Pccn phase [12], 3D single-bonded trigonal nitrogen allotrope (TrigN) [13]. Out of all these phases, experimentally in the pressure range from 120 to $180 \mathrm{GPa}$, only the phase similar to the layered $\mathrm{Pba} 2$ phase was detected [14].

A significant number of theoretical papers in recent years have also been devoted to the search for structures of isolated nitrogen clusters $\mathrm{N}_{m}$ with $m \geq 3$. The structural and energy characteristics of $\mathrm{N}_{3}^{-}[15], \mathrm{N}_{4}[16,17,18], \mathrm{N}_{5}^{-}[19,20]$, $\mathrm{N}_{5}^{+}[20,21], \mathrm{N}_{6}[17,18], \mathrm{N}_{8}[18,22], \mathrm{N}_{10}[23,24], \mathrm{N}_{12}[25,26]$, $\mathrm{N}_{14}$ [25], $\mathrm{N}_{16}$ [25], $\mathrm{N}_{18}[25], \mathrm{N}_{20}[25,27], \mathrm{N}_{24}[25,28,29]$, $\mathrm{N}_{30}$ [28,29], $\mathrm{N}_{32}$ [29], $\mathrm{N}_{36}$ [28, 29], $\mathrm{N}_{40}$ [29], $\mathrm{N}_{42}$ [29], $\mathrm{N}_{48}$ [29], $\mathrm{N}_{54}$ [29], $\mathrm{N}_{56}[29], \mathrm{N}_{60}[1,29,30], \mathrm{N}_{72}[31], \mathrm{N}_{78}$ [32] clusters are studied in detail. Among these clusters, it is worth noting the experimentally synthesized tetranitrogen $\mathrm{N}_{4}$ [16], azide anion $\mathrm{N}_{3}^{-}$[15], pentanitrogen cation $\mathrm{N}_{5}^{+}$[21], and pentanitrogen anion $N_{5}^{-}$[19] that was only detected in the gas phase. Clusters containing a large number of atoms are of particular interest because they allow one to store a large amount of energy. Theoretical works $[28,32,33]$ showed that stabilizing factors for the large nitrogen clusters include the presence of a large number of pentagons and three-membered rings in the structure, as well as the cylindrical structure of the nitrogen cell.

Despite the progress achieved in the physics of nitrogen systems, the problem of creating of metastable extended single-bonded allotropic modifications of nitrogen, that can be stable under normal conditions, remains open. In the presented study, we consider the nitrogen analogs of traditional well-known carbon nanotubes, which, at present, due to their exceptional electronic, mechanical, and optical properties, have found a large number of applications in modern science and technology [34]. The main purpose of this work is to analyze the nitrogen nanotubes that are stable under normal conditions and to study their structural and energy characteristics. In addition, we analyze the prospects of using such systems as high-energy-density materials.

\section{Materials and methods}

In this paper, we consider a family of zigzag and armchair nitrogen nanotubes that are completely similar in structure to the corresponding carbon nanotubes. The diameter of the systems under consideration does not exceed the value of $4.7 \AA$, i. e., our calculations are limited to the systems $(n, 0)$ and $(m, m)$ with $n=3 \div 6$ and $m=2,3$. We investigate the extended systems whose length is about $3 \mathrm{~nm}$. The study of extended systems is of particular interest since they are potentially capable of storing more energy than elementary systems. Calculations are carried out for the nitrogen nanotubes with free (open) ends, as well as in the presence of passivation with hydrogen and hydroxyl groups, and for capped nanotubes.

Geometry optimization and characterization of nitrogen nanotubes were made in terms of density functional theory (DFT). All DFT calculations were performed using the TeraChem software [35-38]. The Becke's three-parameter hybrid method, and the Lee-Yang-Parr exchange-correlation energy functional (B3LYP) $[39,40]$ was used. B3LYP functional was combined with Pople basis set $6-31 \mathrm{G}(\mathrm{d})$ as implemented in TeraChem. During geometry optimization, the global charge of all systems considered was neutral. The maximum force and root mean square forces were $4.5 \times 10^{-4}$ and $3 \times 10^{-4}$ (hartrees per bohr and hartrees per radian), whereas the maximum displacement and root mean square displacement were $1.8 \times 10^{-3}$ and $1.2 \times 10^{-3}$.

\section{Results and discussion}

We studied the stability of different zigzag and armchair nitrogen nanotubes $3 \mathrm{~nm}$ in length. For zigzag tubes, this length corresponds to eight unit cells, for armchair tubes, it corresponds to eleven unit cells. We chose a rather long effective length of the considered systems since the extended systems can store a large amount of energy. The diameter of the considered nitrogen nanotubes does not exceed $d_{m} \leq 4.7 \AA$, i. e., zigzag nanotubes $(n, 0)$ with $n=3-6$ are considered, as well as armchair nanotubes $(m, m)$ with $m=2,3$.

Structural optimization of nitrogen nanotubes has shown that open nanotubes without passivation of the boundary are unstable. The dissociation of such systems occurs due to the separation of the boundary nitrogen atoms with dangling bonds.

In the case of capped nitrogen nanotubes, only $(3,0)$ and $(4,0)$ zigzag nanotubes are thermodynamically stable. The $(3,0)$ nanotube, whose boundary is capped with only one nitrogen atom consists of $98 \mathrm{~N}$ atoms, and we denoted it as $(3,0) \operatorname{NNT}\left(\mathrm{N}_{98}\right)$. Similarly, nitrogen nanotube of type $(3,0)$ with three nitrogen atoms in the cap layer and nanotube of type $(4,0)$ with four nitrogen atoms in the cap layer are denoted as $(3,0) \operatorname{NNT}\left(\mathrm{N}_{102}\right)$ and $(4,0) \operatorname{NNT}\left(\mathrm{N}_{136}\right)$, respectively. Their geometry is shown in Fig. 1. The values of the bond lengths $l_{\|}$and $l_{\perp}$ correspond to the interlayer and intralayer N-N bonds obtained as a result of the geometrical optimization are $l_{\|}=1.488 \AA, l_{\perp}=1.460 \AA$ for nanotubes of type $(3,0)$ and $l_{\|}=1.472 \AA, l_{\perp}=1.444 \AA$ for nanotubes of type 

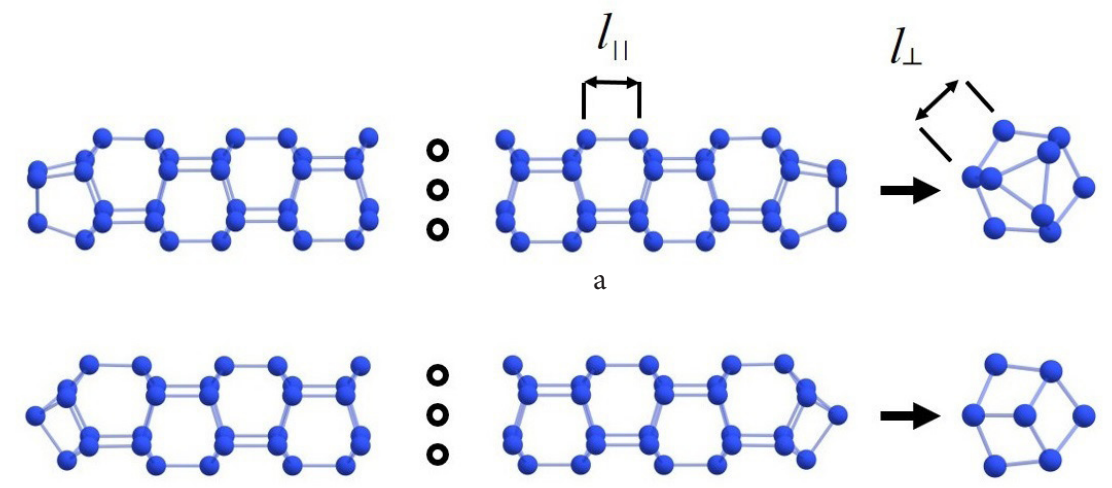

b

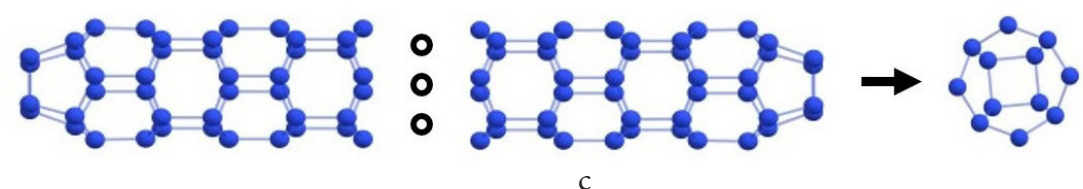

Fig. 1. Atomic structures of the capped nitrogen nanotubes $(3,0) \mathrm{NNT}\left(\mathrm{N}_{102}\right)(\mathrm{a}),(3,0) \mathrm{NNT}\left(\mathrm{N}_{98}\right)(\mathrm{b}),(4,0) \mathrm{NNT}\left(\mathrm{N}_{136}\right)(\mathrm{c})$. Top-side view and bottom-top view. Symbols $l_{\|}$and $l_{\perp}$ correspond to the interlayer and intralayer N-N bonds in the distance of the capped ends, respectively.

$(4,0)$. These values are close to the experimental single N-N bond length of $1.449 \AA$ [30].

The frequency spectrum of capped $(3,0)$ and $(4,0)$ nitrogen nanotubes does not contain imaginary frequencies, that indicates their dynamic stability. Example of the frequency spectrum for stable capped $(3,0) \operatorname{NNT}\left(\mathrm{N}_{102}\right)$ is shown in Fig. 2 (we used Gaussian broadening to transform discrete spectral lines into the continuum spectrum). Nitrogen cage systems that consist only of hexagons are usually unstable. The most striking example, in this case, is nitrogen fullerenes. The geometry of hexagons in the case of nitrogen nanotubes of the types $(3,0)$ and $(4,0)$ is strongly distorted, so they are stable, in contrast to nitrogen nanotubes of larger diameter.

Geometry optimization and calculation of frequency spectra show that in the case when the boundaries of $(3,0)$ and $(4,0)$ nitrogen nanotubes are passivated with functional groups $\mathrm{H}$ and $\mathrm{OH}$, their stability is preserved.

Table 1 presents the values of HOMO-LUMO gaps $\Delta_{\mathrm{HL}}$ and binding energies

$$
E_{b}\left[\frac{\mathrm{eV}}{\text { atom }}\right]=\frac{1}{N_{a t}}\left(n_{\mathrm{H}} E(\mathrm{H})+n_{\mathrm{O}} E(\mathrm{O})+n_{\mathrm{N}} E(\mathrm{~N})-E_{\text {tot }}\right)
$$

where $E(\mathrm{H}), E(\mathrm{O})$, and $E(\mathrm{~N})$ are the energies of isolated $\mathrm{H}$, $\mathrm{O}$, and $\mathrm{N}$ atoms, respectively; $n_{\mathrm{H}}, n_{\mathrm{O}}$ and $n_{\mathrm{N}}$ are the number of $\mathrm{H}, \mathrm{O}$, and $\mathrm{N}$ atoms, respectively; $N_{a t}$ is the total number of atoms in the system; $E_{\text {tot }}$ is the total energy of the system. The HOMO-LUMO gap of these nanotubes is about $4 \mathrm{eV}$. Therefore, such systems can be classified as insulators. The values of the binding energy of the considered systems are close to each other. At the same time, nitrogen nanotubes of type $(3,0)$ possess higher binding energy, which means they are more thermodynamically stable. The most energetically beneficial is the passivation of the nanotube boundaries by the hydrogen atoms.

Finally, to estimate the stored energy in our stable nitrogen nanotubes, we determine the reaction energy for one atom

$$
\Delta E\left[(3,0) \mathrm{NNT}\left(\mathrm{N}_{102}\right) \rightarrow 51 \mathrm{~N}_{2}\right]=\frac{1}{102}\left(51 E\left(\mathrm{~N}_{2}\right)-E_{t o t}\right)
$$

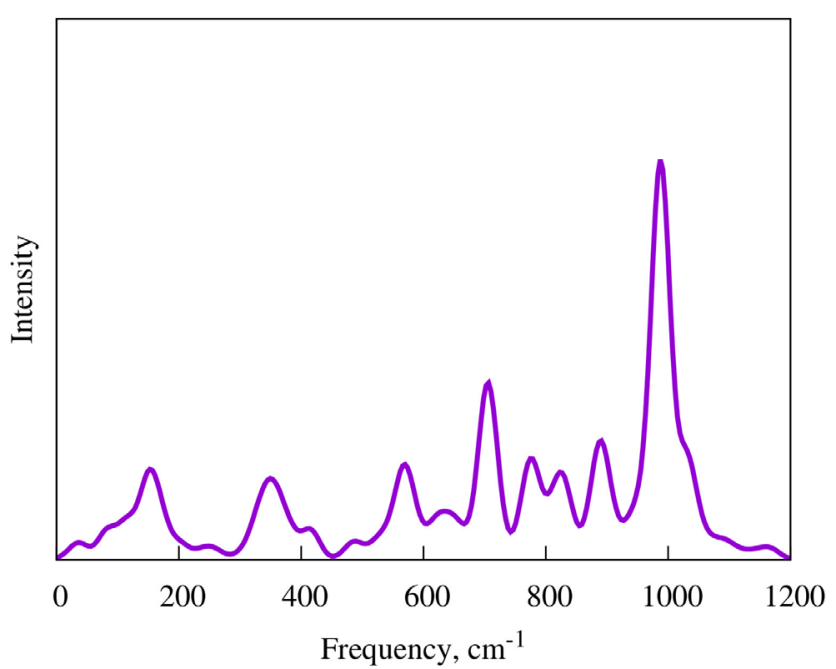

Fig. 2. Frequency spectrum of capped nitrogen nanotube $(3,0) \operatorname{NNT}\left(\mathrm{N}_{102}\right)$.

Table 1. Binding energies $\left(E_{b}\right)$ and HOMO-LUMO gaps $\left(\Delta_{\mathrm{HL}}\right)$ for the stable nitrogen nanotubes.

\begin{tabular}{|c|c|c|}
\hline Nitrogen nanotube & $E_{b}, \mathrm{eV}$ & $\Delta_{\mathrm{HL}}, \mathrm{eV}$ \\
\hline$(3,0) \mathrm{NNT}\left(\mathrm{N}_{98}\right)$ & 2.913 & 4.34 \\
\hline$(3,0) \mathrm{NNT}\left(\mathrm{N}_{102}\right)$ & 2.960 & 4.43 \\
\hline$(3,0) \mathrm{NNT}\left(\mathrm{N}_{96} \mathrm{H}_{6}\right)$ & 2.996 & 4.88 \\
\hline$(3,0) \mathrm{NNT}\left(\mathrm{N}_{96} \mathrm{O}_{6} \mathrm{H}_{6}\right)$ & 2.976 & 4.82 \\
\hline$(4,0) \mathrm{NNT}\left(\mathrm{N}_{136}\right)$ & 2.837 & 3.90 \\
\hline$(4,0) \mathrm{NNT}\left(\mathrm{N}_{128} \mathrm{H}_{8}\right)$ & 2.893 & 4.08 \\
\hline$(4,0) \mathrm{NNT}\left(\mathrm{N}_{128} \mathrm{O}_{8} \mathrm{H}_{8}\right)$ & 2.880 & 4.22 \\
\hline
\end{tabular}

is equal to $1.88 \mathrm{eV} /$ atom. This value is comparable with the calculated energy difference $\Delta E\left[\mathrm{~N}_{4} \rightarrow 2 \mathrm{~N}_{2}\right]=2 \mathrm{eV} /$ atom [30] for experimentally synthesized $\mathrm{N}_{4}[16]$, which demonstrates the prospects of using these systems as the high-energydensity materials. 


\section{Conclusions}

According to the presented calculations, only $(3,0)$ and $(4,0)$ zigzag nitrogen nanotubes with extremely small diameters can be stable under ambient conditions. Their stability can be achieved via the capping or passivation of their ends by the hydrogen atoms or hydroxyl groups. Among all the systems considered, the most energetically feasible is the $(3,0)$ nitrogen nanotube with passivated by hydrogen atoms ends. It can release a large amount of energy during the decomposition to isolated nitrogen molecules. We believe that the obtained results provide a new step toward allnitrogen high-energy-density materials.

Acknowledgments. The reported study was funded by RFBR according to the research project No. 18-32-20139 mol_a_ved.

\section{References}

1. P. C. Samartzis, A. M. Wodtke. Int. Rev. in Phys. Chem. 25 (4), 527 (2006). Crossref

2. C. Mailhiot, L.H. Yang, A. K. McMahan. Physical Review B. 46 (22), 14419 (1992). Crossref

3. M.I.Eremets, A. G. Gavriliuk, N.R. Serebryanaya, I. A. Trojan, D.A. Dzivenko, R. Boehler, H.K. Mao, R.J. Hemley. The Journal of Chemical Physics. 121 (22), 11296 (2004). Crossref

4. M.M. G. Alemany, J.L. Martins. Phys. Rev. B. 68, 024110 (2003). Crossref

5. W. D. Mattson, D. Sanchez-Portal, S. Chiesa, R. M. Martin. Phys. Rev. Lett. 93, 125501 (2004). Crossref

6. F. Zahariev, A. Hu, J. Hooper, F. Zhang, T. Woo. Phys. Rev. B. 72, 214108 (2005). Crossref

7. A.R. Oganov, C. W. Glass. J. Chem. Phys. 124, 244704 (2006). Crossref

8. F. Zahariev, J. Hooper, S. Alavi, F. Zhang, T. K. Woo. Phys. Rev. B. 75, 140101 (R) (2007). Crossref

9. J. Kotakoski, K. Albe. Phys. Rev. B. 77, 144109 (2008). Crossref

10. Y. Ma, A. R. Oganov, Z. Li, Y. Xie, J. Kotakoski. Physical Review Letters. 102, 065501 (2009). Crossref

11. J. Sun, M. Martinez-Canales, D.D. Klug, C.J. Pickard, R. J. Needs. Physical Review Letters. 111, 175502 (2013). Crossref

12. A. A. Adeleke, M.J. Greschner, A. Majumdar, B. Wan, H. Liu, Z. Li, H. Gou, Y. Yao. Physical Review B. 96, 224104 (2017). Crossref

13. S. V. Bondarchuk, B. Minaev. Phys. Chem. Chem. Phys. 19, 6698 (2017). Crossref

14. D. Tomasino, M. Kim, J. Smith, C.-S. Yoo. Physical Review Letters. 113, 205502 (2014). Crossref

15. T.M. Klapotke. New Nitrogen-Rich High Explosives. In: High Energy Density Materials. Structure and Bonding. Vol. 125. Berlin, Springer-Verlag GmbH (2007). p. 85-121. Crossref
16. F. Cacase, G. Petris, A. Troiani. Science. 295, 480 (2002). Crossref

17. S. Ajith Perera, R. J. Bartlett. Chem. Phys. Lett. 314, 381 (1999). Crossref

18. W. J. Lauderdale, J. F. Stanton, R. J. Bartlett. J. Phys. Chem. 96, 1173 (1992). Crossref

19. A. Vij, J. Pavlovich, W. Wilson, V. Vij, K. Christe. Angew. Chem. Int. Ed. 41, 3051 (2002). Crossref

20. A. Vij, W.W. Wilson, V. Vij, F.S. Tham, J.A. Sheehy. J. Am. Chem. Soc. 123, 6308 (2001). Crossref

21. K. Christe, W. Wilson, J. Sheehy, J. Boatz. Angew. Chem. Int. Ed. 38, 2004 (1999). Crossref

22. M. Schmidt, M. Gordon, J. Boatz. Int. J. Quantum Chem. 76, 434 (2000). Crossref

23. S. Fau, K. J. Wilson, R. J. Bartlett. J. Phys. Chem. A. 106, 4639 (2002). Crossref

24. L. J. Wang, P. G. Mezey, M.Z. Zgierski. Chemical Physics Letters. 391 (4-6), 338 (2004). Crossref

25. C. Chen, S.-F. Shyu. International Journal of Quantum Chemistry. 73 (4), 349 (1999). Crossref

26. M. N. Glukhovtsev, H. Jiao, P. von R. Schleyer. Inorganic Chemistry. 35 (24), 7124 (1996). Crossref

27. T.-K. Ha, O. Suleimenov, M. T. Nguyen. Chemical Physics Letters. 315 (5-6), 327 (1999). Crossref

28. D. L. Strout. The Journal of Physical Chemistry A. 108 (13), 2555 (2004). Crossref

29. H. Zhou, N.-B. Wong, G. Zhou, A. Tian. The Journal of Physical Chemistry A. 110 (10), 3845 (2006). Crossref

30. M.R. Manaa. Chemical Physics Letters. 331 (2-4), 262 (2000). $\underline{\text { Crossref }}$

31. H. Zhou, N.-B. Wong, G. Zhou, A. Tian. The Journal of Physical Chemistry A. 110 (23), 7441 (2006). Crossref

32. H. Zhou, N.-B. Wong, A. Tian. Journal of Molecular Graphics and Modelling. 25 (4), 578 (2006). Crossref

33. L.Y. Bruney, T.M. Bledson, D.L. Strout. Inorganic Chemistry. 42 (24), 8117 (2003). Crossref

34. P. Slepička, T. Hubáček, Z. Kolská, S. Trostová, N. Slepičková Kasálková, L. Bačáková, V. Švorčík. The Properties and Application of Carbon Nanostructures, In: Polymer Science. IntechOpen (2013). Crossref

35. I.S. Ufimtsev, T. J. Martínez. J. Chem. Theory Comput. 5, 2619 (2009). Crossref

36. A. V. Titov, I. S. Ufimtsev, N. Luehr, T. J. Martínez, J. Chem. Theory Comput. 9, 213 (2013). Crossref

37. J. Kästner, J.M. Carr, T.W. Keal, W. Thiel, A. Wander, P. Sherwood. J. Phys. Chem. A. 113, 11856 (2009). Crossref

38. T. P. M. Goumans, C. R. A. Catlow, W. A. Brown, J. Kästner, P. Sherwood. Phys. Chem. Chem. Phys. 11, 5431 (2009). Crossref

39. C. Lee, W. Yang, R. G. Parr. Phys. Rev. B. 37, 785 (1988). Crossref

40. A. D. Becke. J. Chem. Phys. 98, 5648 (1993). Crossref 